\title{
Rapid Adaptation and Continuous Performance Evaluation of SARS-CoV-2 Envelope Gene (E-gene) Real-Time RT-PCR Assays to Support the Hospital Surge in Test Demand
}

Yolanda lok leng Ho ( $\sim$ hii801@ha.org.hk )

Prince of Wales Hospital

\section{Ann Han Wong}

Department of Microbiology, Prince of Wales Hospital

\section{Eddie Chi Man Leung}

Department of Microbiology, Prince of Wales Hospital

River Chun Wai Wong

Department of Microbiology, Prince of Wales Hospital

\section{Raymond Wai Man Lai}

Department of Microbiology, Prince of Wales Hospital

\section{Short report}

Keywords: SARS-Co-V-2, E-gene, Real-time RT-PCR

Posted Date: July 8th, 2020

DOI: https://doi.org/10.21203/rs.3.rs-38621/v1

License: (c) (i) This work is licensed under a Creative Commons Attribution 4.0 International License. Read Full License

Version of Record: A version of this preprint was published at Journal of Medical Virology on November 22nd, 2020. See the published version at https://doi.org/10.1002/jmv.26660. 


\section{Abstract}

We describe timely adaption of both published WHO E-gene protocol and commercially available LightMix Modular E-gene assay to the test platform (ABI 7900 Fast real-time analyzer and TaqMan Fast One-step Virus Master Mix) available in an accredited tertiary hospital laboratory with on-going evaluation to ensure provision of quality service within time constraint. The LightMix Modular E-gene was slightly more sensitive when compared to the WHO E-gene, both analytically and diagnostically. The assay was recommended for screening of SARS-CoV-2 infection. With the availability of technically competent staff through continuous training, provision of round the clock service is feasible despite the test is of high complexity. The shorten turn-around-time of about 4 hours per batch could support surges in testing demand, which is essential to control the current SARS-CoV-2 pandemic, to prevent potential overwhelming of the healthcare system and to optimize utilization of the isolation beds.

\section{Background}

The severe acute respiratory syndrome coronavirus 2 (SARS-CoV-2) was first reported in Wuhan, China, in the end of December 2019 [1]. The genome published on January 11th 2020 (GenBank accession number MN908947) shows a high similarity to the SARS-CoV-1 which was epidemic in Hong Kong in 2003 [2]. Early February 2020, there were 42,708 confirmed infections and 1017 fatalities in China [3]. To control disease spread and prevent outbreak which could overwhelm the healthcare system, rapid implementation and provision of quality assured molecular diagnostic service is crucial.

Owing to its immediate availability, the LightMix Modular E-gene assay (Tib-Molbiol, Germany) designed for use with the LightCycler 480 system and the LightCycler multiplex RNA virus master (both are from Roche Diagnostics, Germany) was implemented in our laboratory for emergency use on 1st February 2020. An alternative E-gene protocol published by Corman et al [4] is recommended by World Health Organization (WHO) [5] and is widely used for screening of SARS-CoV-2 in Europe [6, 7]. Here we reported the timely adaption of published protocol and commercial assay to our routine testing platform with on-going performance evaluation to ensure provision of quality service by a National Association of Testing Authorities (NATA, Australia) accredited laboratory.

\section{Objective}

The aim of this study was to adapt and compare the performance of the WHO E-gene and the LightMix Egene using $A B I 7900$ Fast real-time analyzer and TaqMan Fast Virus One-step Master Mix (both are from Applied Biosystems, USA) for screening of the SARS-CoV-2 in respiratory samples.

\section{Study Design}

\subsection{Nucelic acid extraction}


Nucleic acids were extracted with the MagMax ${ }^{\mathrm{TM}} 96$ viral RNA isolation kit using the MagMax high throughput nucleic acid processor (both are from Applied Biosystems, USA). Sample input volume was $200 \mu \mathrm{l}$ and elution volume was $50 \mu \mathrm{l}$.

\subsection{Adapted LightMix E-gene and WHO E-gene set up}

Final reaction volume was $20 \mu \mathrm{l}$ with $5 \mu \mathrm{l}$ of the 4 x TaqMan Fast Virus One-step Master Mix and $10 \mu \mathrm{l}$ of template. The LightMix E-gene assay contained $0.5 \mu \mathrm{l}$ of the E-gene parameter specific reagent. For the WHO E-gene assay, the primers (E_Sarbeco_F and E_Sarbeco_R) and BHQ1 probe (E_Sarbeco_P1) sequences (Tib-Molbiol, Germany) and their final concentrations recommended by Corman et a/ were adopted. Thermal cycling conditions with the $\mathrm{ABI} 7900$ Fast real-time analyzer were $55^{\circ} \mathrm{C}$ for $5 \mathrm{~min}, 95^{\circ} \mathrm{C}$ for $20 \mathrm{~s}$, followed by 40 cycles of $95^{\circ} \mathrm{C}$ for $3 \mathrm{~s}$ and $60^{\circ} \mathrm{C}$ for $30 \mathrm{~s}$ with data acquisition for the LightMix Egene but $58{ }^{\circ} \mathrm{C}$ for the WHO E-gene. For both assays, RNA extracted from positive samples and nucleasefree water were used as positive and no template control respectively.

\subsection{Analytical performance}

The limits of detection (LoD) of both assays were assessed with the Exact Diagnostics SARS-CoV-2 standard (Exact Diagnostics, USA) which was diluted to 200, 100, 50 and 25 copies per mL. Each dilution was extracted with the MagMax system and tested 5 times with each assay. Four pooled samples (Pool 1 to Pool 4, Table 1) were prepared from the ZeptoMetrix respiratory verification panel 2 (ZeptoMetrix, USA) to assess their analytical specificities. MERS-CoV RNA from the 2016 Quality Control and Molecular Diagnostics (QCMD) panel and SARS-CoV-1 RNA provided by Public Health Laboratory Services Branch (PHLSB) of Hong Kong were also tested. Precision was evaluated with the RNA control with cycle threshold (Ct ) 28 which was tested in five separate runs. 
Table 1

Pools of respiratory pathogens prepared from ZeptoMetrix respiratory verification panel 2

\begin{tabular}{|ll|}
\hline Organism & Organism \\
\hline Pool 1 & Pool 2 \\
\hline Adenovirus Type 3 & Rhinovirus 1A \\
\hline Influenza A 2009 H1N1 & Influenza A subtype H3 \\
\hline Influenza B & Coronavirus 229E \\
\hline Parainfluenza virus Type 4 & Parainfluenza virus Type 1 \\
\hline Coronavirus OC43 & Parainfluenza virus Type 2 \\
\hline Pool 3 & Pool 4 \\
\hline Adenovirus Type 1 & Adenovirus Type 31 \\
\hline Influenza A H1N1 & Bordetella pertusis \\
\hline Parainfluenza virus Type 3 & Chlamydia pneumoniae \\
\hline Respiratory syncytial virus A & Mycoplasma pneumoniae \\
\hline Coronavirus NL63 & Coronavirus HKU1 \\
\hline Bordetella parapertusis & Human Metapneumovirus 8 \\
\hline
\end{tabular}

\subsection{Accuracy}

Both assays were assessed with the QCMD Coronavirus outbreak preparedness (CVOP) external quality assurance (EQA) pilot scheme issued in end of April 2020. The samples were extracted with the MagMax system followed by testing with both protocols.

\subsection{Diagnostic performance}

Ninety respiratory samples from non-duplicated patients ( 3 sputum; 62 pooled nasopharyngeal swab and throat swab; 23 pooled nasopharyngeal aspirate and throat swab; and 2 deep throat saliva), were tested by both protocols. All E-gene positive cases were further confirmed by PHLSB which is one of the WHO designated reference laboratories. Using the WHO E-gene as the reference method, diagnostic sensitivity and specificity of the LightMix E-gene were evaluated. Discrepancies were resolved with i) the Xpert Xpress SARS-CoV-2 assay (Cepheid, USA); ii) results of confirmation by PHLSB; iii) clinical information and availability of additional SARS-CoV-2 test results. 


\section{Results}

When tested with the Exact Diagnostics standard, the LightMix E-gene and WHO E-gene could detect down to 4 and 8 copies/reaction (equivalent to 100 and $200 \mathrm{copies} / \mathrm{mL}$ ) respectively. These were within the confidence interval reported by the manufacturer and by Corman et al. Both assays did not cross-react with MERS-CoV RNA and the various respiratory pathogens listed in Table 1 but could detect SARS- CoV-1 RNA. Both assays were also precise with $\mathrm{CV}$ less than $3 \%$ when tested with the positive control in five separate runs.

When assessed with the eight EQA samples, both assays gave correct results with comparable Ct values. The borderline positive sample was detected by both assays and reproducible results $(\Delta \mathrm{Ct}=0.14)$ were also obtained for the duplicate samples in the scheme.

For the clinical samples, correlation of the results by both assays was shown in Table 2:

Table 2

Correlation of the WHO E-gene results with the LightMix E-gene results

\begin{tabular}{|c|c|c|c|c|c|}
\hline & & \multicolumn{4}{|c|}{ WHO E-gene } \\
\hline & & Detected & Equivocal & Not detected & Total \\
\hline \multirow[t]{4}{*}{ LightMix E-gene } & Detected & 39 & 1 & 2 & 42 \\
\hline & Equivocal & 0 & 0 & 0 & 0 \\
\hline & Negative & 0 & 0 & 48 & 48 \\
\hline & Total & 39 & 1 & 50 & \\
\hline
\end{tabular}

There were 3 samples with discordant results (Table 2). After resolving discrepancies, they can be categorized as true positive or false positive (Table 3) with diagnostic sensitivity and specificity listed in Table 4: 
Table 3

Characteristics of the discordant specimens

\begin{tabular}{|c|c|c|c|c|c|c|}
\hline $\begin{array}{l}\text { Specimen } \\
\text { (Sample type) }\end{array}$ & $\begin{array}{l}\text { WHO E- } \\
\text { gene } \\
\text { result }\end{array}$ & $\begin{array}{l}\text { LightMix } \\
\text { E-gene } \\
\text { result } \\
\text { (Ct) }\end{array}$ & $\begin{array}{l}\text { Xpert } \\
\text { Xpress } \\
\text { SARS CoV- } \\
2 \text { result } \\
\text { (Ct of E } \\
\text { gene/ Ct of } \\
\text { N2 gene) }\end{array}$ & $\begin{array}{l}\text { PHLSB } \\
\text { confirmatory } \\
\text { test result }\end{array}$ & $\begin{array}{l}\text { Medical } \\
\text { record } \\
\text { review }\end{array}$ & $\begin{array}{l}\text { Final } \\
\text { categorization }\end{array}$ \\
\hline $\begin{array}{l}1 \\
\text { (pooled } \\
\text { nasopharyngeal } \\
\text { swab and } \\
\text { throat swab) }\end{array}$ & $\begin{array}{l}\text { Equivocal } \\
\text { (FAM } \\
\text { signal) }\end{array}$ & $\begin{array}{l}\text { Detected } \\
(35.94)\end{array}$ & $\begin{array}{l}\text { Detected } \\
(35.7 / 39.2)\end{array}$ & Detected & - & True positive \\
\hline $\begin{array}{l}2 \\
\text { (pooled } \\
\text { nasopharyngeal } \\
\text { swab and } \\
\text { throat swab) }\end{array}$ & $\begin{array}{l}\text { Not } \\
\text { detected }\end{array}$ & $\begin{array}{l}\text { Detected } \\
(34.92)\end{array}$ & $\begin{array}{l}\text { Detected } \\
(34.3 / 36.8)\end{array}$ & Equivocal & $\begin{array}{l}\text { SARS- } \\
\text { CoV-2 } \\
\text { RNA was } \\
\text { detected } \\
\text { in sputum } \\
\text { of this } \\
\text { patient }\end{array}$ & True positive \\
\hline $\begin{array}{l}3 \\
\text { (Deep throat } \\
\text { saliva) }\end{array}$ & $\begin{array}{l}\text { Not } \\
\text { detected }\end{array}$ & $\begin{array}{l}\text { Detected } \\
(37.34)\end{array}$ & $\begin{array}{l}\text { Not } \\
\text { detected }\end{array}$ & Not detected & $\begin{array}{l}\text { Patient } \\
\text { attended } \\
\text { AED but } \\
\text { there was } \\
\text { no fever. } \\
\text { Additional } \\
\text { sample } \\
\text { was not } \\
\text { available }\end{array}$ & False positive \\
\hline
\end{tabular}

Table 4

Diagnostic sensitivity and specificity of the LightMix E-gene assay for diagnosis of SARS CoV-2 infection

\begin{tabular}{|llll|}
\hline & \multicolumn{3}{|c|}{ SARS-CoV-2 } \\
\hline \multirow{2}{*}{$\begin{array}{l}\text { LightMix } \\
\text { E-gene }\end{array}$} & Detected & 41 & 1 \\
\cline { 2 - 4 } & Not detected & 0 & 48 \\
\hline & Diagnostic sensitivity: $100.00 \%$ \\
& $(95 \% \mathrm{Cl}=91.40$ to $100.00 \%)$ \\
\hline & Diagnostic specificity: $97.962 \%$ \\
& $(95 \% \mathrm{Cl}=89.15-99.95 \%)$ \\
\hline
\end{tabular}




\section{Discussion}

Molecular diagnostic is regarded as high-complexity work which requires specific training. Various molecular diagnostic platforms such as the GeneXpert and Filmarray are now available for point-of-care testing (POCT). However, when novel pathogen such as the SARS-CoV-2 emerges, timely implementation of a sustainable molecular diagnostic service is important. Availability of technically competent staff familiar with the conventional workflows is a challenge. Our laboratory has experience with providing in-house influenza A/B and respiratory syncytial virus real-time RT-PCR testing to cope with the increase in demand during winter surge [8] and a team of technically competent staff is available. Despite published protocols and pre-mixed primers and probes are available commercially, the testing platform available in our laboratory was different. This study showed how published protocol and commercial kit can be adapted immediately with continuous evaluation to provide quality service within time constraint.

The LoDs of both adapted assays were in line with those reported by the manufacturer and by Corman et al. Both assays were analytically specific and performance was good when assessed with the QCMD pilot run samples. Using the adapted WHO E-gene as the reference method, the LightMix E-gene was diagnostically sensitive (sensitivity $=100.00 \% ; 95 \% \mathrm{Cl}=91.40$ to $100.00 \%$, Table 4 ) while diagnostic specificity was $97.96 \%(95 \% \mathrm{Cl}=89.15-99.95 \%$, Table 4$)$. To avoid unnecessary quarantine, contact tracing and other public health issues, confirmation of any positive result by this assay is essential and we send these samples to PHLSB for confirmation.

Variation in instrument and reagents might affect performance of published protocols. Konrad et al reported that a relative high proportion of non-specific signal is found in the Corman et alprotocol when an alternative one-step RT-PCR system was used [9]. This was not observed in our adapted protocol. Recently Okamato et al [10] and Yip et al [11] also reported that the LightMix E-gene assay was sensitive when compared to their corresponding reference method. After the rapid adaptation and implementation of the LightMix E-gene within 48 hours in early February, we continuously evaluated the assays to ensure test quality. The turn-around-time (TAT) is approximately 4 hours and we now provide 5 batches of run daily with testing capacity of about 350 . This shorten TAT greatly facilitates isolation bed utilization.

\section{Conclusion}

In conclusion, the LightMix Modular E-gene assay adapted for use with our testing platform is sensitive and suitable for initial screening. Continuous training to maintain a team of competent staff familiar with conventional molecular testing is crucial in particular when novel pathogen emerges and sample-to-answer automated system is not available.

\section{Abbreviations}

SARS-CoV-2: Severe acute respiratory syndrome coronavirus 2; WHO: World Health Orgination; NATA: National Association of Testing Authorities; LoD: Limit of detection; QCMD: Quality Control and Molecular 
Diagnostics; PHLSB: Public Health Laboratory Services Branch; CVOP: Coronavirus outbreak preparedness; EQA: external quality assurance; Ct: cycle threshold; POCT: point-of-care testing

\section{Declarations}

\section{Acknowledgements:}

We thank Mr Chan Kwan Lun and Mr Yeung Yuk Lam for their excellent technical support. We are also grateful to all staff of the Virology Division for their contribution to ad hoc set up of the round the clock molecular service during this pandemic.

\section{Authors' contribution}

Yolanda II Ho: Planned and conducted experiments in optimization of the adapted protocols, data analysis and wrote the manuscript draft. Ann $\mathrm{H}$ Wong: conceptualised the comparison, co-writing the manuscript. Eddie CM Leung: coordinated the study and set up the live run of the ad hoc round the clock service. River CW Wong: verification of the Xpert Xpress SARS-CoV-2 assay for discrepancy resolution, co-ordinate specimen storage and retrieval. Raymond WM Lai: conceptualisation and review the manuscript. All authors read and approve the final manuscript.

\section{Funding:}

This research did not receive any specific grant from funding agencies in the public, commercial, or not-forprofit sectors.

\section{Availability of data and materials:}

All data generated and analyzed during this study are included in this report.

\section{Ethical approval:}

Anonymized samples were tested and ethical approval was not required.

\section{Consent for publication:}

Not applicable

\section{Competing interests}


The authors declare that we have no competing interests.

\section{References}

1. Zhu N, Zhang D, Wang W, Li X, Yang B, Song J, et al. A novel coronavirus from patients with pneumonia in China. N Engl J Med. 2020;382(8):727-733. https://doi.org/10.1056/NEJM0a2001017 PMID: 31978945.

2. Wu F, Zhao S, Yu B, Chen YM, Wang W, Song ZG, et al. A new coronavirus associated with human respiratory disease in China. 2020; 579(7798): 265-269. https://doi.org/10.1038/s41586-020-2008-3 PMID: 32015508

3. Novel Coronavirus (2019-nCoV) situation report-12. Accessed on 11-2-2020.

4. Corman VM, Landt O, Kaiser M, Molenkamp R,Meijer A, Chu DKW et al. Detection of 2019 novel coronavirus (2019-nCoV) by real-time RT-PCR. Euro Surveill. 2020;25(3):2000045. https://doi.org/10.2807/1560-7917. 2020.25.3.2000045 PMID:31992387.

5. World Health Organization. 2020. Laboratory testing strategy recommendations for COVID-19: Interim guidance, 21 March 2020. World Health Organization, Geneva, Switzerland. https://apps.who.int/iris/handle/10665/331509. (Accessed 21-3-2020)

6. Haveri A, Smura T, Kuivanen S, Österlund P, Hepojoki J, Ikonen $\mathrm{N}$ et al. Serological and molecular findings during SARS-CoV-2 infection: the first case study in Finland, January to February 2020. Euro Surveill 2020;25(11): https://doi.org/10.2807/1560-7917. ES.2020.25.11.2000266. PMID: 32209163.

7. Reusken CBEM, Broberg EK, Haagmans B, Meijer A, Corman VM, Papa A etal. Laboratory readiness and response for novel coronavirus (2019-nVoV) in expert laboratories in 30 EU/EEA countries. January 2020. Euro Surveill25(6):pii=2000082. https://doi.org/10.2807/1560-7917.ES.2020.25.6.2000082. PMID:32046815.

8. Ho YII, Wong A, Lai RWM. Comparison of the Cepheid Xpert Xpress Flu/RSV Assay with in-house Flu/RSV triplex real-time RT-PCR for Rapid Molecular Detection of Influenza A, Influenza B and Respiratory Syncytial Virus in respiratory specimens. J Med Microbiol 2018;67(11):1576-1580. https:// doi: 10.1099/jmm.0.000841 PMID: 30207514.

9. Konrad R, Eberie U, Dangel A, Treis B, Berger A, Bengs K et al. Rapid establishment of laboratory diagnostics for the novel coronavirus SARS-CoV-2 in Bavaria, Germany, February 2020. Euro Surveill 2020;25(9):2000173. https://doi.org/2807/1560-7917.ES.2020.25.9.2000173. PMID: 32156330

10. Okamaoto K, Shirato K, Nao N, Saito S, Kageyama T, Hasegawa H et al. An assessment of real-time RTPCR kits for SARA-CoV-2 detection. Jpn J Infect Dis 2020 Apr 30.

https://doi.org/7883/yoken.JJID.2020.108. PMID: 32350226.

11. Yip CCY, Sridhar S, Cheng AKW, Leung KH, Choi GKY, Chen JHK et al. Evaluation of the commercially available LightMix Modular E-gene kit using clinical and proficiency specimens for SARS-CoV-2 detection. J Clin Virol 129(2020) 104476. https://doi.org/10.1016/j.jcv.2020.104476 